\title{
Endogenous Enforcement Institutions
}

Gani ALDASHEV and Giorgio ZANARONE

CRED - January 2014

Department of Economics

Working Papers

2014/03

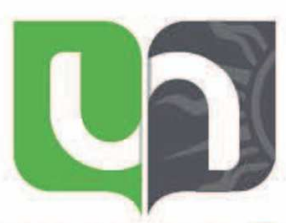

UNIVERSITE

DE NAMUR 


\title{
Endogenous Enforcement Institutions
}

\author{
Gani ALDASHEV* and Giorgio ZANARONE ${ }^{* *}$
}

January 2014

\begin{abstract}
We model the State as a self-enforcing agreement over the use of force. A principal contracts with an agent, and a powerful ruler enforces their contracts through a mix of monetary fines and coercion. If the ruler fails to enforce, or if he uses his power to expropriate, all parties revert to low production forever after. Our model has two important implications. First, a better coercion technology moves the optimal system from private ordering, where contracts are enforced by the threat of termination, to the State, where they are enforced by the threat of coercion. This is consistent with the historical correlation between improvements in coercion and the transition from the "Law Merchant" enforcement system to the State. Second, contract enforcement and non-expropriation are complementary inputs in the State, in the sense that improvements in the enforcement technology increase the agent's effort only if the ruler has limited expropriation power, so that the ruler's incentive constraint on contractual enforcement is binding. This result relates to the Acemoglu and Johnson (2005) finding that constraints on rulers have affected the development of nations more than improvements in contractual enforcement. Using their data we find that, consistent with our model, contractual enforcement does affect development, but only when the ruler's expropriation power is sufficiently constrained.
\end{abstract}

Keywords: Enforcement; Punishment; Coercive power; Relational contracts; State. JEL codes: D23; K42; P37.

\footnotetext{
${ }^{*}$ University of Namur and ECARES, ULB; e-mail: gani.aldashev@unamur.be. ${ }^{* *}$ Colegio Universitario de Estudios Financieros (CUNEF); e-mail: gzanarone@cunef.edu. We are grateful to Robert Gibbons for extensive advice and suggestions. We also thank Benito Arruñada, Scott Ashworth, Tim Besley, V. Bhaskar, Alessandro Bonatti, Ethan Bueno de Mesquita, Antonio Cabrales, Andrea Canidio, Paul Castañeda Dower, Marco Celentani, Jonathan Conning, Giuseppe Dari-Mattiacci, Angel Hernando, Avner Greif, Carmine Guerriero, Ruitian Lang, Antoine Loeper, Scott Masten, Dilip Mookherjee, Pablo Montagnes, Roger Myerson, Andy Newman, JeanPhilippe Platteau, Debraj Ray, Heikki Rentakari, Lorenzo Sacconi, Giancarlo Spagnolo, Arthur Silve, Kaj Thomsson, John Wallis, Barry Weingast, Birger Wernerfelt, Stephane Wolton, and seminar audiences at the University of Ottawa, Hunter College, Carlos III, MIT, Stockholm School of Economics, University of Turin, University of Chicago, University of Namur, University of Cergy-Pontoise, and at the AEA, SIDE, ALEA, THRED, ISNIE, ACLE, TILEC, and DIAL conferences, for useful comments. This study received financial support from the Spanish Ministry of Science and Education, through grant ECO2011-29445.
} 


\section{Introduction}

Coercive power has an ambiguous social role. On one hand, it encourages investment by enabling the punishment of anti-social behavior. On the other hand, it discourages investment by permitting expropriation and theft. ${ }^{1}$ This ambiguity has been sometimes described as "the fundamental political dilemma" (Weingast 1995). In this paper, we address the dilemma by formally modeling the State as a self-enforcing agreement over the use of force. Our model has two goals: (1) investigating when a State's ruler can commit to use his power to enforce contracts between citizens rather than to expropriate them, and (2) assessing to what extent coercive contract enforcement by the State performs better than private ordering solutions, such as bilateral relationships and communities.

In our model there are three parties: a principal, an agent, and a ruler endowed with coercive power. The principal contracts the agent to perform a task in exchange for a salary. The agent performs only if he expects the principal to pay him the promised salary, and the ruler not to expropriate it. In the absence of enforcement mechanisms neither expectation is fulfilled, and the resulting equilibrium is characterized by low productivity and income.

If the parties interact repeatedly, better equilibria can be achieved by conditioning continuation of the relationship to the principal's and the ruler's present behavior. In

\footnotetext{
${ }^{1}$ On the economic theory of conflict and expropriation, and the related literature, see Hirschleifer (2001).
} 
particular, the principal may prefer to pay the agent today and receive higher surplus in the future from the agent's increased effort, and the ruler may prefer not to expropriate the agent today and collect part of the future surplus through taxation. This is the "private ordering" solution familiar from the literatures on relational contracts (e.g., Levin 2002, 2003), community enforcement (e.g., North et al. 1990; Milgrom et al. 1994), and selfenforcing political institutions (e.g., Olson 1993; Weingast 1995; Acemoglu 2003; de Figueiredo and Weingast 2005).

As an alternative to pure private ordering, we explore the possibility that the principal and the agent create a State by appointing the ruler as an enforcer. In the State, two instruments are used to punish the principal if he fails to pay the agent (or equivalently, if he disobeys a court's order to pay). First, the ruler may impose a monetary penalty (for instance, by increasing taxes or by imposing a fine). Second, the ruler may inflict a costly coercive punishment on the principal (for instance, by imprisoning him). The ruler cannot be punished coercively, so his repeated interaction with the principal and the agent is used to prevent expropriation, as under private ordering. In addition, the repeated interaction is also used to provide the ruler with an incentive to inflict costly punishments when needed, so that the State's threat of coercion is credible.

Our analysis has two important implications. First, improvements in the coercion technology should move the optimal enforcement system from private ordering, where contracts are enforced by a threat to terminate the principal-agent relationship, to the State, where contracts are enforced by a threat of coercion. This result provides a possible explanation for why, in parallel with steady reductions in the cost of coercion over history 
(Blaydes and Chaney 2012; Onorato et al. 2012), the medieval private enforcement system known as Law Merchant has been gradually replaced by court-enforcement systems backed by the State's coercive power (Milgrom et al. 1990; Masten and Prüfer 2011).

Second, our model implies that in a State, effective contract enforcement and secure property rights are complementary inputs. When the ruler's power to expropriate is limited by exogenous factors, his contract enforcement incentive constraint is more likely to bind than his non-expropriation constraint, so improvements in the enforcement technology increase productive effort and performance. Conversely, when the ruler's power to expropriate is unlimited, his contract enforcement constraint is less likely to bind, and improvements in the enforcement technology do not matter for efficiency. This result relates to the empirical puzzle noted by Acemoglu and Johnson (2005), who find that exogenous constraints on the rulers have favored the economic development of nations more than improvements in contractual enforcement. Using the data and identification strategy employed by Acemoglu and Johnson, we find that, consistent with our theoretical predictions, improvements in contractual enforcement do matter for efficiency, but only when the ruler's power is sufficiently constrained. Our results on the relative importance of contract enforcement and non-expropriation are also consistent with the fact that, facing expropriatory institutions inherited from Mao's Cultural Revolution, Chinese reformers have privileged the protection of property rights, while leaving contract enforcement institutions, and particularly the judiciary, relatively underdeveloped (Montinola et al. 1995; Weingast 1995; Peerenboom 2002; Clarke et al. 2008; Xu 2011). 
This paper reconciles three streams of economic literature. The first stream, on formal contracts, emphasizes the role of courts and the State in enforcing contractual obligations (Djankov et al. 2002, 2003, Glaeser and Shleifer 2002). ${ }^{2}$ The second stream emphasizes how self-enforcing agreements, which are sustained by the parties' interest in maintaining bilateral or multilateral relationships rather than by the threat of coercion, can generate "order without law". ${ }^{3}$ The third stream, on self-enforcing political institutions, focuses on how the State can credibly commit not to use violence in order to expropriate citizens (Olson 1993; Weingast 1995; Acemoglu et al. 2001, 2002; Acemoglu 2003; de Figueiredo and Weingast 2005; Gibbons and Rutten 2007; North et al. 2009).

Our contribution to these literatures is twofold. First, we show that, since coercive enforcement of private contracts by the State is costly, it must be itself part of a selfenforcing agreement. This implies that State enforcement cannot be taken for granted even when contracts are perfectly verifiable by courts, and that whether it performs better than private enforcement depends on the coercion technology. Second, we show that in a State, the ruler's duties to enforce contracts and respect property rights interact and, therefore, should be jointly analyzed, rather than studied in isolation.

The rest of the paper is organized as follows. Section 2 presents the model. Section 3 analyzes private ordering. Section 4 analyzes the State and compares it to private

\footnotetext{
${ }^{2}$ Exogenous State enforcement is assumed by most works on incentive contracts (e.g., Holmstrom 1979; Holmstrom and Milgrom 1991), incomplete contracts (e.g., Hart and Moore 1988; Battigalli and Maggi 2002), and property rights (e.g., Grossman and Hart 1986; Arruñada 2003; Libecap and Lueck 2011). ${ }^{3}$ Self-enforcing agreements have been used to study employment contracts (MacLeod and Malcomson 1989; Baker et al. 1994; Levin 2002, 2003), inter-firm contracts (Klein 2000; Zanarone 2013), the structure and boundaries of firms (Baker et al. 1999, 2002), property rights (Ellickson 1991), and enforcement by markets and communities (Klein and Leffler 1981; Bendor and Mookherjee 1990; Milgrom et al. 1990; Greif et al. 1994; Dixit 2003a, 2003b; Masten and Prüfer 2011; Hadfield and Weingast 2012a, 2012b). See Dixit (2004), Greif (2006), and MacLeod (2007) for comprehensive reviews of these literatures.
} 
ordering. Section 5 applies the model to observed institutions. Section 6 discusses possible extensions of the model and concludes.

\section{A model of contracts in the shadow of coercion}

\subsection{Environment and technology}

There are a principal, an agent and a ruler, who controls the territory where the principal and the agent live. All parties are risk-neutral, live forever, and discount nextperiod incomes at the common factor $1 /(1+r)$. The principal has an exogenous monetary income of $\omega_{\mathrm{p}}$ per period, which we may interpret as the return from assets he owns in other territories. The ruler also has an exogenous monetary income $\omega_{\mathrm{R}}$. We assume that $\omega_{\mathrm{P}}$ and $\omega_{\mathrm{R}}$ are large enough for all the monetary payments in the model to be feasible. ${ }^{4}$

\section{Production}

Production occurs as in a standard agency model: by spending effort $e$ at cost $\mathrm{C}(\mathrm{e})$, the agent generates endogenous income $\mathrm{V}(\mathrm{e})$ for the principal. We assume that $\mathrm{V}(\cdot)$ and $\mathrm{C}(\cdot)$ are increasing in $e, \mathrm{~V}(0)=\mathrm{C}(0)=0$, and the per period surplus $\mathrm{V}(\mathrm{e})-\mathrm{C}(\mathrm{e})$ has a unique global maximizer $\mathrm{e}^{\mathrm{FB}}>0$.

\footnotetext{
${ }^{4}$ The agent may also have an exogenous income. Since this plays no role in the model, we normalize it to zero.
} 


\section{Coercion}

The ruler controls coercive power within his territory. By incurring cost $k \lambda(\mathrm{L})$, the ruler can use his power to inflict disutility $L$ to either the principal or the agent, where $\lambda(\mathrm{L})$ is the ruler's coercion effort, $k$ is the unit cost of such effort, and it is assumed that $\lambda(0)=0$ and $\lambda^{\prime}(\cdot)>0$. The coercion cost $k \lambda(L)$ may be interpreted as the ruler's expenditure to equip and transport soldiers, maintain weapons, and administer detention facilities, as well as the monetary equivalent of the psychological cost suffered by the ruler for causing pain to the principal and the agent.

The ruler may use coercion to either expropriate or punish. We assume that, since the principal and the agent are both harmless, the ruler can expropriate their endogenous income with a small use of coercion (for instance, by keeping them detained just for the short time necessary to collect their money and walk away), so that $\mathrm{L} \approx \mathrm{k} \lambda(\mathrm{L}) \approx 0$. In contrast, punishment requires the ruler to inflict substantial pain, and hence to incur a higher coercion cost.

While the ruler can expropriate inside his territory at little coercion cost, his expropriation capability is subject to two constraints. First, the principal's exogenous income $\omega$ cannot be expropriated - for instance, because it is prohibitively costly for the ruler to exert coercion outside his territory (Acemoglu 2003). Second, and related, the principal and the agent may be able to transfer part of their endogenous incomes outside 
the ruler's territory, so that the ruler can only expropriate a share $\psi \in[0,1]$ of such incomes. ${ }^{5}$ When the ruler faces a lower $\psi$, we say that he is more constrained.

\section{Information and timing}

In any given period $\mathrm{s}$, the sequence of events is as follows:

1. The principal makes a (possibly negative) monetary transfer $t_{\mathrm{s}}$ to the ruler.

2. The agent spends effort $\mathrm{e}_{\mathrm{s}}$, incurring $\operatorname{cost} \mathrm{C}\left(\mathrm{e}_{\mathrm{s}}\right)$.

3. The principal pays a bonus $b_{s}$ to the agent.

4. The principal receives value $\mathrm{V}\left(\mathrm{e}_{\mathrm{s}}\right)$ from the agent's effort.

5. The ruler grabs a share $\gamma_{\mathrm{s}}$ of the principal's income $\mathrm{V}\left(\mathrm{e}_{\mathrm{s}}\right)$, and a share $\beta_{\mathrm{s}}$ of the agent's income $b_{s}$, where $\gamma_{s}, \beta_{s} \in[0, \psi]$. The ruler may also inflict a coercive punishment $\mathrm{L}_{\mathrm{s}}$ to the principal, the agent, or both.

All together, the endogenous variables $b_{s}, t_{s}, \gamma_{s}, \beta_{s}$, and $L_{s}$, determine the distribution of surplus between the principal, the agent and the ruler, as well as the agent's incentives to work, the principal's incentives to reward the agent, and the ruler's incentives to exert coercion.

We assume throughout the model that all actions (efforts, punishments, expropriation, and payments) are publicly observed.

\footnotetext{
${ }^{5}$ For instance, citizens of a colony located in an area with low population density may have more opportunities to escape a dispotic ruler or hide their wealth from him (Acemoglu et al. 2002; Acemoglu and Robinson 2012).
} 


\subsection{Equilibrium in the absence of enforcement}

Given our definitions and assumptions, we can state the following:

Proposition 1: There is a subgame-perfect equilibrium, called non-enforcement, where in every period: (1) no upfront transfer between the principal and the ruler occurs $\left(t_{s}=0\right),(2)$ the agent spends no effort $\left(e_{s}=0\right),(3)$ the principal pays no bonus to the agent $\left(b_{s}=0\right)$, and (4) the ruler does not inflict any coercive punishments $\left(\mathrm{L}_{\mathrm{s}}=0\right)$.

Proof: Given non-enforcement, the ruler's best response at stage 5 of period s is not to punish $\left(\mathrm{L}_{\mathrm{s}}=0\right)$ and to grab as much as possible from the principal's and agent's incomes $\left(\gamma_{\mathrm{s}}=\beta_{\mathrm{s}}=\psi\right)$. Anticipating that, the principal's best response at stage 3 is to pay no bonus $\left(b_{s}=0\right)$, the agent's best response at stage 2 is to spend no effort $\left(\mathrm{e}_{\mathrm{s}}=0\right.$ ), and the principal's and ruler's best response at stage 1 is to make no transfer $\left(\mathrm{t}_{\mathrm{s}}=0\right) \cdot \mathrm{QED}$.

\section{Non-coercive enforcement: private ordering}

Since in the absence of enforcement no surplus is generated, it is natural to ask whether more efficient equilibria can be achieved. As a benchmark, we first consider the 
"private ordering" solution studied by Greif et al. (1994) and others, where cooperation is enforced by a threat to terminate exchange in future periods. ${ }^{6}$

We formally define private ordering as a subgame-perfect equilibrium where, in any given period $s, 1)$ the principal makes monetary transfer $t$ to the ruler, 2) the agent spends effort $\left.\mathrm{e} \in\left(0, \mathrm{e}^{\mathrm{FB}}\right], 3\right)$ the principal pays $b$ to the agent, and 4$)$ the ruler grabs $\gamma \mathrm{V}(\mathrm{e})$ from the principal and $\beta b$ from the agent (for instance, by imposing additional taxes). If anybody deviates, all parties revert to the non-enforcement strategies from period $\mathrm{s}$ and thereafter. We interpret $\gamma$ and $\beta$ as income tax rates applied by the ruler to the principal's and agent's incomes, respectively.

For effort $e$ to be part of a private ordering equilibrium, two sets of conditions must hold. First, all parties must be willing to initiate and continue in each period the multilateral relationship (participation constraints):

$$
\begin{aligned}
& t+\gamma \mathrm{V}(\mathrm{e})+\beta \mathrm{b} \geq 0 \text { for the ruler, } \\
& (1-\gamma) \mathrm{V}(\mathrm{e})-\mathrm{t}-\mathrm{b} \geq 0 \text { for the principal, and } \\
& (1-\beta) \mathrm{b}-\mathrm{C}(\mathrm{e}) \geq 0 \text { for the agent. }
\end{aligned}
$$

Second, the principal must be willing to pay the agent for his effort, and the ruler must be willing not to expropriate the agent and the principal - that is, to tax them more than allowed by the equilibrium strategies (incentive constraints): ${ }^{7}$

\footnotetext{
${ }^{6}$ Private ordering enforcement is also studied by the literature on relational contracts (e.g., Baker et al. 1994, 2002; Levin 2002, 2003). Unlike Greif et al. (1994), relational contracting models do not allow for a ruler with the power to expropriate.
} 


$$
\begin{aligned}
& -\mathrm{b}+(1-\gamma) \mathrm{V}(\mathrm{e})+\frac{1}{\mathrm{r}}\{(1-\gamma) \mathrm{V}(\mathrm{e})-\mathrm{t}-\mathrm{b}\} \geq(1-\psi) \mathrm{V}(\mathrm{e}) \text {, and } \\
& \gamma \mathrm{V}(\mathrm{e})+\beta \mathrm{b}+\frac{1}{\mathrm{r}}\{\gamma \mathrm{V}(\mathrm{e})+\beta \mathrm{b}+\mathrm{t}\} \geq \psi[\mathrm{b}+\mathrm{V}(\mathrm{e})] .
\end{aligned}
$$

Summing up (1) through (3) yields $V(e)-C(e) \geq 0$, which is satisfied for any effort in the relevant range, $e \in\left(0, e^{\mathrm{FB}}\right]$. Summing up (4) and (5) and choosing the minimum bonus acceptable for the agent, $\mathrm{b}=\frac{\mathrm{C}(\mathrm{e})}{1-\beta}$, yields:

$$
\left(1+\frac{\psi}{1-\beta}\right) \mathrm{C}(\mathrm{e}) \leq \frac{1}{\mathrm{r}}[\mathrm{V}(\mathrm{e})-\mathrm{C}(\mathrm{e})]
$$

By optimally setting $\beta=0$, we obtain the following necessary condition for effort e to be part of a private ordering equilibrium:

$$
(1+\psi) \mathrm{C}(\mathrm{e}) \leq \frac{1}{\mathrm{r}}[\mathrm{V}(\mathrm{e})-\mathrm{C}(\mathrm{e})]
$$

where "EC $\mathrm{P}^{\mathrm{P}}$ " stands for "private-ordering constraint". It is easy to check that, when $\left(E C^{\mathrm{P}}\right)$ holds, there are values of $\mathrm{t}$ and $\gamma$ such that (1) through (5) also hold, so that $\left(\mathrm{EC}^{\mathrm{P}}\right)$ is both necessary and sufficient. ${ }^{8}$ This immediately implies the following

\footnotetext{
${ }^{7}$ We omit the agent's incentive constraint because they are identical to the participation constraint (3). If the agent does not spend effort, the principal will not pay him a bonus in period s, and the non-enforcement equilibrium, where the agent spends no effort and the principal pays no bonus, will apply from period s +1 and thereafter.

${ }^{8}$ For instance, when $\left(\mathrm{EC}^{\mathrm{P}}\right)$ holds, (1) through (5) hold for $\mathrm{t}=(1-\gamma) \mathrm{V}(\mathrm{e})-\mathrm{C}(\mathrm{e})$ and $\gamma=\psi-\frac{\mathrm{C}(\mathrm{e})}{\mathrm{V}(\mathrm{e})}$.
} 
Proposition 2: the most efficient effort level that can be sustained in a private ordering equilibrium, $\mathrm{e}^{\mathrm{P}}$, maximizes the total surplus $\mathrm{V}(\mathrm{e})-\mathrm{C}(\mathrm{e})$, subject to $\left(\mathrm{EC}^{\mathrm{P}}\right)$.

Proposition 2 implies that $\mathrm{e}^{\mathrm{P}}$ approaches the first best effort $\mathrm{e}^{\mathrm{FB}}$ when the parties are patient enough (low r) and when the ruler is more constrained (low $\psi$ ). Notice that $\mathrm{e}^{\mathrm{P}}$ does not depend on $\gamma$, the share of the agent's output that goes to the ruler in equilibrium, because the reduction in the principal's gain from deviation obtained by lowering $\gamma$ (condition 4) is offset by an equal increase in the ruler's temptation to expropriate (condition 5). To illustrate proposition 2, Figure 1 below depicts the private ordering equilibrium $\mathrm{e}^{\mathrm{P}}$ for low and high values of $\mathrm{r}$ and $\psi .{ }^{9}$

$$
<<\text { Place Figure } 1 \text { here }>>
$$

Notice that, in defining private ordering, we have assumed stationary equilibria where the parties' actions are the same in any given period. This assumption is without loss of generality. In the absence of coercive punishments, reversion to non-enforcement is the strongest credible sanction against deviations (Abreu 1988). Moreover, the discretionary payments $t$ and $b$, which are used to distribute surplus between the principal, the agent and the ruler, are publicly observed. Then, theorems 2 and 3 in Levin (2003) imply that a non-stationary equilibrium where the agent's effort changes over time cannot generate greater surplus than the stationary private equilibrium described in proposition 2 , where the agent spends effort $\mathrm{e}^{\mathrm{P}}$ in every period. ${ }^{10}$

\footnotetext{
${ }^{9}$ In Figure 1, it is assumed that the cost of effort $\mathrm{C}(\cdot)$ is linear.

${ }^{10}$ See also MacLeod and Malcomson (1989).
} 


\section{Coercive enforcement: the State}

Since $\mathrm{e}^{\mathrm{P}}$ is the best self-enforcing equilibrium in the absence of coercive punishments, it is natural to ask whether the principal, the agent and the ruler can accomplish more by creating a State - that is, by appointing the ruler to coercively enforce contracts between the principal and the agent. ${ }^{11}$

\subsection{State equilibria}

We formally define the State as a subgame-perfect equilibrium where, in any given period s: 1) the principal makes monetary transfer $t$ to the ruler, 2) the agent spends effort $\left.\mathrm{e} \in\left(0, \mathrm{e}^{\mathrm{FB}}\right], 3\right)$ the principal pays bonus $\mathrm{b}$ to the agent, and 4$)$ the ruler grabs $\gamma \mathrm{V}(\mathrm{e})$ from the principal and nothing from the agent. ${ }^{12}$ As in section 3 , the restriction to stationary equilibria is without loss of generality.

If the principal and the ruler do not honor the upfront transfer $t$, or if the ruler expropriates the principal and the agent through an arbitrary increase in taxation, all parties revert to non-enforcement forever after, as under private ordering. If the principal fails to pay $b$ to the agent, private ordering punishments are partially substituted by the ruler's coercion. In particular, in period s, in addition to raising the principal's income tax

\footnotetext{
${ }^{11}$ In modern States, contract breach is typically not followed by a coercive punishment but, rather, by a court's order imposing monetary damages. However, the court's order is itself backed by a threat of coercion: if the losing defendant does not pay damages as ordered, he can be held in contempt of court-a criminal offense - and imprisoned.

${ }^{12}$ We have shown in section 3 on private ordering that it is optimal for the agent not to share his income with the ruler $(\beta=0)$. Since this result applies identically under the State, we posit upfront it in defining the equilibrium strategies to economize on notation.
} 
(a monetary punishment), the ruler inflicts on the principal a coercive punishment L. ${ }^{13}$ If the ruler punishes the principal following contract breach, in period $\mathrm{s}+1$ and in all subsequent periods, the principal, the agent and the ruler continue to play the State equilibrium. Finally, if the ruler fails to inflict coercive punishment $\mathrm{L}$ on the principal following breach, all parties revert to non-enforcement forever after.

Reversion to non-enforcement is the strongest possible punishment against the ruler's deviations, because the ruler monopolizes power and, therefore, he cannot be himself punished via coercion. It will become clear in a moment that continuation of the principal-agent-ruler relationship after the principal deviates and the ruler punishes him is also an efficient off-the-equilibrium strategy (see footnote 15).

For effort e to be part of a State equilibrium, as defined above, participation constraints (1)-(3), and the ruler's non-expropriation constraint (5), must still hold. The principal's incentive constraint (4) from private ordering is replaced by the condition that the ruler's coercive punishment be strong enough to deter contract breach:

$$
-b+(1-\gamma) V(e) \geq(1-\psi) V(e)-L
$$

In addition, the ruler must have an incentive to impose a coercive punishment when the principal breaches:

\footnotetext{
${ }^{13}$ We assume it is less costly to inflict disutility L through an immediate punishment in period s than through a sequence of punishments.
} 


$$
-\mathrm{k} \lambda(\mathrm{L})+\frac{1}{\mathrm{r}}\{\gamma \mathrm{V}(\mathrm{e})+\mathrm{t}\} \geq 0 .^{14}
$$

If the ruler's incentive constraints (5) and (7) hold for some transfer t, they must hold for the maximum transfer that satisfies the principal's participation constraint (2), that is, $\mathrm{t}=(1-\gamma) \mathrm{V}(\mathrm{e})-\mathrm{b}$. Similarly, if the ruler's incentive constraints hold for some bonus $\mathrm{b}$ and punishment $\mathrm{L}$, they must hold for the minimum values of $\mathrm{b}$ and $\mathrm{L}$ that satisfy the agent's participation constraint (3) and the principal's incentive constraint (6), that is, $\mathrm{b}=\mathrm{C}(\mathrm{e})$ and $\mathrm{L}=\mathrm{b}-(\psi-\gamma) \mathrm{V}(\mathrm{e})$, respectively. Substituting these values into the ruler's participation constraint (1), we obtain the condition $\mathrm{V}(\mathrm{e})-\mathrm{C}(\mathrm{e}) \geq 0$, which holds for any $\mathrm{e} \in\left(0, \mathrm{e}^{\mathrm{FB}}\right]$. Substituting into the ruler's incentive constraints (5) and (7), we obtain the following two necessary and sufficient conditions:

$$
\begin{aligned}
& \mathrm{k} \lambda\{\mathrm{C}(\mathrm{e})-(\psi-\gamma) \mathrm{V}(\mathrm{e})\} \leq \frac{1}{\mathrm{r}}[\mathrm{V}(\mathrm{e})-\mathrm{C}(\mathrm{e})] \text {, and } \\
& \psi \mathrm{C}(\mathrm{e})+(\psi-\gamma) \mathrm{V}(\mathrm{e}) \leq \frac{1}{\mathrm{r}}[\mathrm{V}(\mathrm{e})-\mathrm{C}(\mathrm{e})]
\end{aligned}
$$

The notation "EC $\mathrm{H}$ " stands for "horizontal constraint", and determines the ruler's incentive to enforce the principal-agent contract. We call this constraint "horizontal" because both parties in the principal-agent contract lack coercive power and, therefore, are hierarchically similar. The notation " $\mathrm{EC}$ "” stands for "vertical constraint", and determines the ruler's incentive not to expropriate the principal and the agent. We call

\footnotetext{
${ }^{14}$ We drop $\psi \mathrm{V}(\mathrm{e})$, the ruler's expropriation following deviation by the principal, because it appears on both sides of (7).
} 
this constraint "vertical" because the ruler has power and, therefore, he is hierarchically superior to both the principal and the agent.

From the above analysis, it immediately follows that

Proposition 3: For any given $\gamma$, the most efficient effort level that can be sustained in a State equilibrium, $\mathrm{e}^{\mathrm{s}}(\gamma)$, maximizes the surplus $\mathrm{V}(\mathrm{e})-\mathrm{C}(\mathrm{e})$, subject to $\left(\mathrm{EC}^{\mathrm{H}}\right)$ and $\left(\mathrm{EC}^{\mathrm{V}}\right)$.

An immediate and intuitive implication of proposition 3 is that the optimal State equilibrium is weakly decreasing in the coercion cost $\mathrm{k}$. A less immediate implication, analyzed below, regards the relative importance of the ruler's two tasks - contract enforcement and non-expropriation — in defining the State equilibrium. ${ }^{15}$

Notice that a decrease in the equilibrium tax $\gamma$ increases the monetary penalty the principal suffers from the ruler when he fails to pay the agent, thereby reducing the need for the ruler to impose costly coercive punishments. This relaxes the contract enforcement constraint $\left(\mathrm{EC}^{\mathrm{H}}\right)$, but it also tightens the non-expropriation constraint $\left(\mathrm{EC}^{\mathrm{V}}\right)$, because it increases the ruler's short-run gains from expropriation. By optimally choosing $\gamma$, we obtain have the following

\footnotetext{
${ }^{15}$ Conditions $\left(\mathrm{EC}^{\mathrm{H}}\right)$ and $\left(\mathrm{EC}^{\mathrm{V}}\right)$ are both satisfied by setting t so that the principal gets zero in equilibrium. This implies that our posited off-the-equilibrium strategy - whereby, following contract breach by the principal and punishment by the ruler, all parties keep playing the State equilibrium - is efficient, in the sense that it relaxes the equilibrium conditions as much as possible. To see why, notice first that, if the ruler is to punish contract breach, the principal and the ruler must continue their relationship after the principal breaches and the ruler punishes him, or else the ruler will have no incentive to punish in the first place. Suppose next that the agent terminates his relationship with the principal in period $s+1$ if the principal fails to pay him in period s. Then, the principal's payoff in period $s+1$ would be zero, as in the State equilibrium, whereas the ruler's payoff would be lower than his State payoff due to the decrease in output. As a result, the ruler's punishment constraint would be tighter than $\left(\mathrm{EC}^{\mathrm{H}}\right)$, which implies that continuation of the State equilibrium following deviation by the principal and punishment by the ruler is efficient.
} 
Proposition 4: Assume the discount rate is moderate, so that at least one between the ruler's non-expropriation and enforcement constraints binds in equilibrium. Then, (i) there is a critical $\mathrm{k}^{*}$, increasing in $\psi$, such that the contract enforcement constraint is slack at low coercion costs $\left(\mathrm{k} \leq \mathrm{k}^{*}\right)$, and binding otherwise, and (ii) there is a critical $\psi^{*}$, increasing in $\mathrm{k}$, such that the non-expropriation constraint is slack at low levels of the ruler's expropriation capability $\left(\psi<\psi^{*}\right)$, and binding otherwise.

Proof: Part (i). Let $\gamma=\psi$, so that $\left(\mathrm{EC}^{\mathrm{V}}\right)$ is loosest and $\left(\mathrm{EC}^{\mathrm{H}}\right)$ tightest. At $\mathrm{k}=0\left(\mathrm{EC}^{\mathrm{H}}\right)$ is slack, and it becomes tighter as $\mathrm{k}$ grows, so there must be $\mathrm{k}^{*}>0$ such that $\left(\mathrm{EC}^{\mathrm{H}}\right)$ is slack if, and only if $\mathrm{k}<\mathrm{k}^{*}$. When $\mathrm{k}<\mathrm{k}^{*}$, setting $\gamma=\psi$ is optimal because it relaxes the binding constraint. When $\mathrm{k}>\mathrm{k}^{*}$, it is optimal to decrease $\gamma$ until both $\left(\mathrm{EC}^{\mathrm{H}}\right)$ and $\left(\mathrm{EC}^{\mathrm{V}}\right)$ bind, or until $\gamma=0$ if $\left(\mathrm{EC}^{\mathrm{V}}\right)$ is slack at $\gamma=0$. This implies that in equilibrium, $\left(\mathrm{EC}^{\mathrm{H}}\right)$ is slack for $\mathrm{k}<\mathrm{k}^{*}$, and binding for $\mathrm{k}>\mathrm{k}^{*}$. Moreover, $\left(\mathrm{EC}^{\mathrm{H}}\right)$ and and $\left(\mathrm{EC}^{\mathrm{V}}\right)$ imply that $\mathrm{k}^{*}=0$ for $\psi=0$, and that $\mathrm{k}^{*}$ grows larger the larger $\psi$. The proof of part (ii) follows from a similar argument. QED.

Intuitively, proposition 4 suggests that contract enforcement and non-expropriation are complementary inputs in the State's success. When the ruler's power to expropriate is exogenously limited (low $\psi)$, the non-expropriation constraint $\left(\mathrm{EC}^{\mathrm{V}}\right)$ is unlikely to bind, so what equilibrium can be achieved under the State primarily depends on the contract enforcement constraint $\left(\mathrm{EC}^{\mathrm{H}}\right)$. If that is the case, it is optimal to give the ruler a small output share by setting a low equilibrium tax $\gamma$, because that creates a credible expropriation threat against the principal if he breaches his contract with the agent, which 
partially substitutes costly coercive punishments and thus relaxes the ruler's enforcement constraint. Moreover, exogenous reductions in the enforcement cost k enhance efficiency because they relax the binding enforcement constraint.

When the ruler's power to expropriate is not subject to exogenous limits (high $\psi$ ), the opposite is true: the contract enforcement constraint is unlikely to bind, so it is optimal to give the ruler a large output share, and exogenous reductions in the ruler's enforcement cost $\mathrm{k}$ do not affect the equilibrium and, hence, they do not matter for efficiency. These results, which are summarized in Figure 2 below, have important implications for economic development and policy. We will return on these in section 5.

$$
<<\text { Place Figure } 2 \text { here }>>
$$

\subsection{State versus private ordering}

In sections 3 and 4, we have analyzed optimal equilibria given the choice of using private ordering or, alternatively, the State, to enforce principal-agent contracts. But which of the two enforcement systems is preferable from an efficiency standpoint? The Folk theorem implies that multiple equilibria exist under both private ordering and the State. However, if the principal, the agent and the ruler can communicate and negotiate (for instance, through political campaigning, lobbying, and the media), they may be able to coordinate, explicitly or implicitly, on an equilibrium.

Then, a natural criterion for ranking the State and private ordering is to compare the optimal equilibria $\mathrm{e}^{\mathrm{P}}$ and $\mathrm{e}^{\mathrm{S}}$. Since the long-term surplus from maintaining the social contract between the principal, the agent and the ruler (the right-hand side of $\left(\mathrm{EC}^{\mathrm{P}}\right)$, 
$\left(\mathrm{EC}^{\mathrm{H}}\right)$ and $\left.\left(\mathrm{EC}^{\mathrm{V}}\right)\right)$ is the same under both enforcement regimes, the State dominates private ordering (in the sense that $\mathrm{e}^{\mathrm{FB}} \geq \mathrm{e}^{\mathrm{S}} \geq \mathrm{e}^{\mathrm{P}}$ ) if, and only if the ruler's reneging temptation under the State (the maximum left-hand side among $\left(\mathrm{EC}^{\mathrm{H}}\right)$ and $\left(\mathrm{EC}^{\mathrm{V}}\right)$ ) is smaller than the ruler's and principal's aggregate reneging temptation under private ordering (the left-hand side of $\left(\mathrm{EC}^{\mathrm{P}}\right)$ ). Proposition 4 implies that, at low coercion costs $\left(\mathrm{k} \leq \mathrm{k}^{*}\right)$, the reneging temptation is $\mathrm{C}(\mathrm{e})$ under the State and $(1+\psi) \mathrm{C}(\mathrm{e})$ under private ordering, so the State dominates. At higher coercion costs $\left(\mathrm{k}>\mathrm{k}^{*}\right)$, the reneging temptation under the State increases in $\mathrm{k}$, while the reneging temptation under private ordering does not depend on $\mathrm{k}$. Hence, there must be a critical coercion cost $\mathrm{k}^{* *} \geq \mathrm{k}^{*}$ such that private ordering dominates for $\mathrm{k} \geq \mathrm{k}^{* *}$, and the State dominates for $\mathrm{k}<\mathrm{k}^{* *}$. These results are summarized by the following:

Proposition 5: Assume that the principal, the agent and the ruler can coordinate on an optimal equilibrium. Then, the State dominates private ordering when the punishment cost is low $\left(\mathrm{k}<\mathrm{k}^{* *}\right)$, whereas private ordering dominates when the punishment cost is $\operatorname{high}\left(\mathrm{k} \geq \mathrm{k}^{* *}\right)$.

This is an intuitive result: since under the State the principal's contract breach is punished by the ruler, whereas under private ordering it is punished via termination of the principal-agent-ruler relationship, the State is more attractive than private ordering when punishments are not too costly for the ruler, and viceversa. Hence, insofar as the parties are reasonably capable of coordinating, they will "hire" the powerful ruler to enforce principal-agent contracts when the punishment cost is low, whereas they will enforce such contracts privately when the punishment cost is high. Despite being intuitive, this 
result is novel. As discussed in the introduction, most models of contracts assume that, when breach is verifiable (as assumed in this paper), the State will enforce contracts, so private ordering solutions are suboptimal. By explicitly modeling the ruler's punishment technology, we show that this is not necessarily the case: State enforcement is costly, so it must be itself part of a self-enforcing agreement, and whether the State wins its "horserace" with private ordering depends on the punishment technology.

\section{Applications}

\subsection{State vs. private ordering: From the Law Merchant to the State}

Proposition 5 predicts that, when the cost of coercion is sufficiently low, the optimal enforcement system should shift from private ordering to the State. This seems consistent with the historical evidence. From the medieval stirrup to the introduction of firearms and remotely controlled weapons (e.g., Kontler 2006; Blaydes and Chaney 2012; Onorato et al. 2012), there have been steady improvements in the ability of States to use coercion. In parallel, Europe has witnessed an evolution in contract enforcement methods from the medieval Law Merchant, where breaches of commercial contracts were punished by coordinated traders' boycotts, to modern State enforcement, where judicial rulings on contractual disputes between merchants are backed by the State's coercive power (Milgrom et al. 1990; Masten and Prüfer 2011). According to our model, by decreasing the ruler's cost of enforcing contracts via coercion, the historical improvements in 
military technology may have favored enforcement of contracts by the State over the Law Merchant's non-coercive enforcement system. ${ }^{16}$

\subsection{Expropriation vs. enforcement (1): The Acemoglu-Johnson "puzzle" revisited}

According to Proposition 4, protection of property rights from expropriation by the ruler and enforcement of contracts by the ruler are complementary inputs in the State. In particular, exogenous improvements in the contract enforcement technology are more likely to increase the agent's effort when the ruler's expropriation capability is constrained, and viceversa.

The relative impact of property rights and contract enforcement on economic development has been empirically investigated by Acemoglu and Johnson (2005). On one hand, they find that former colonies that inherited stronger property rights from their colonizers developed faster. ${ }^{17}$ On the other hand, they find that after controlling for property rights protection, colonies that inherited more flexible and efficient court systems did not perform significantly better than those with more formalistic systems. In what follows, we briefly rivisit Acemoglu and Johnson (2005) in the light of our model, and provide an explanation for their empirical results.

\footnotetext{
${ }^{16}$ Another explanation, complementary tomours, has been suggested by Masten and Prüfer (2011). They argue that the evolution from local to long-distance trade may have increased the merchants' cost of verifying other merchant's violations, thus favoring State enforcement systems that do not rely on coordinated boycotts as a punishment.

${ }^{17}$ Based on Acemoglu et al. (2001), Acemoglu and Johnson (2005) argue that colonizers of inhospitable lands did not settle in, and created institutions aimed at extracting resources from the local population, which persisted into the present. Similarly, based on Djankov et al. (2003), Acemoglu and Johnson (2005) argue that the colonies of common law countries maintained through the present less formalistic systems for adjudicating contractual disputes compared to the colonies of civil law countries.
} 
In terms of our model, an exogenous improvement in property rights can be interpreted as a reduction in the ruler's expropriation capability $\psi$. To incorporate court quality into the model, we relax our assumption of perfect public monitoring and assume that the ruler can observe and punish contract breach by the principal only with probability $\mathrm{q} \in[0,1)$. The ruler's expropriation and punishment actions continue to be publicly observable. This implies that the minimum punishment that the ruler must threaten to deter breach is now $\frac{\mathrm{C}(\mathrm{e})}{\mathrm{q}}-(\psi-\gamma) \mathrm{V}(\mathrm{e})$, which decreases in $\mathrm{q}^{18}$

Figure 3 below illustrates how exogenous changes in court quality affect the State equilibrium for given levels of the ruler's expropriation capability. As the ruler's expropriation capability switches from high (panel a) to intermediate (panel b) to low (panel c), the ruler's contract enforcement constraint is more likely to bind in equilibrium and, consequently, exogenous increases in court quality (from q to q') are more likely to reduce the ruler's reneging temptation and improve the State equilibrium. If this prediction is correct, the null effect of court quality on development documented by Acemoglu and Johnson (2005) should turn positive once the interaction between property rights and court quality is accounted for.

\footnotetext{
${ }^{18}$ With imperfect verification, the ruler may commit two types of mistakes. First, as emphasized above, he may fail to punish P following breach. Second, he may wrongly punish P if P withdraws the bonus when the agent does not spend effort. We can rule out this second type of mistake, and the possibility of opportunistic lawsuits by the agent, by assuming that, if the agent sues opportunistically and the ruler discovers it, the ruler may inflict a small punishment on him. Since the agent does not directly benefit from a lawsuit (if the lawsuit is successful, the principal will be punished but the agent will gain nothing), the threat of a small punishment will prevent the agent from suing opportunistically. Morever, if the punishment agains opportunistic lawsuits is small enough, its cost to the ruler will be close to zero, so that the punishment threat will be credible.
} 
$<<$ Place Figure 3 here $>>$

We use the original Acemoglu and Johnson (2005) cross-country dataset of past European colonies to verify whether these implications are empirically confirmed. Given the potential endogeneity of contract enforcement and property-rights quality, we use their original instruments: UK legal origin as an instrument for legal formalism (interpreted by Acemoglu and Johnson (2005) as an inverse measure of contract enforcement quality), and population density in 1500s as an inverse instrument for constraints on the executive in 1990s (interpreted by Acemoglu and Johnson (2005) as a measure of property-rights quality). ${ }^{19}$ Moreover, and following Wooldridge (2002, chapter 18) and Wooldridge (2003), we use the interaction between these two instruments as an instrument for the interaction of legal formalism and constraints on the executive.

$<<$ Place Table 1 here $>>$

Table 1 describes our estimation results. Column 1 reports the original two-stage least-squares (2SLS) estimation by Acemoglu and Johnson (2005, table 4, column 2). Conditional on the validity of instruments, property-rights seem to have a positive and large causal effect on countries' economic performance, whereas the quality of contract enforcement does not seem to affect it. In columns 2 and 3, we repeat the original regression for two sub-samples, splitting the sample along the log population density in 1500 s. Indeed, in the countries that had higher-than-median population density in $1500 \mathrm{~s}$

\footnotetext{
${ }^{19}$ We use log population density in 1500s (the second instrument of Acemoglu and Johnson (2005)) instead of log settler mortality (their first instrument), so as to maximize the sample size (60 countries instead of 51). Indeed, if settler mortality is used as an instrument, the coefficients are consistent with the ones obtained by using population density, but statistically less significant.
} 
(and thus, as argued by Acemoglu et al. 2001, inherited less secure property rights), the quality of contract enforcement does not have a positive effect on economic performance (the coefficient on formalism is actually positive, implying that in these countries, poorer contract enforcement leads to higher income per capita). Contrarily, in ex-colonies with lower-than-median population density in 1500s (and hence more secure property rights), the quality of contract enforcement seems to have a positive effect on economic performance, with a coefficient close to conventional significance levels. This indicates that property rights and contract enforcement may be complementary.

In column 4, we add to the full-sample regression an interaction term between the quality of contract enforcement and property rights (instrumented by the interaction between UK legal origin dummy and log population density in 1500s). We find that the interaction term carries a negative (and statistically significant at 90\% level) sign: as we move from economies with low protection against the risk of expropriation by the ruler to those with better protection, the effect of legal formalism on economic performance turns negative. ${ }^{20}$ Finally, in column 5 we report the simple OLS regression results, without instrumenting: the coefficients on all the three variables carry the same signs as in the previous regressions, but the sizes are much smaller, which indicates that omitted variable/reverse causality problems are likely to be present, so the use of instrumental variables is justified.

\footnotetext{
${ }^{20}$ At the lowest levels of constraints on the executive (value equal to 1), the relationship between income and the quality of contract enforcement is $y=-9.63+4.06^{*}$ Legal formalism, whereas at the highest levels of constraints on the executive (value equal to 7 ), this relationship is $y=15.39-1.58 *$ Legal formalism.
} 
These findings imply that, consistent with previous empirical work (e.g., Djankov et al. 2002, 2003), the effect of contract enforcement quality on long-run development might be more important than suggested by Acemoglu and Johnson (2005). However, and consistently with our theoretical predictions, contract enforcement seems to matter only in those countries where property rights are sufficiently protected against expropriation from powerful elites, so that the ruler's incentive constraint on enforcing contracts is not dominated by his incentive constraint on respecting property rights.

\subsection{Expropriation vs. enforcement (2): China's reforms}

The history of China's recent economic reforms is also consistent with our analysis of the State. At the time of Mao's death, China was characterized by a strong collectivist ideology inherited from the Cultural Revolution (Xu 2011). After Mao's death, Deng Xiaoping and his successors pursued a drastic ideological shift from collectivism to economic growth. To achieve this goal, they purged party ranks from the most prominent collectivist leaders (including Mao's wife), while filling the party with leaders favorable to the new agenda.

This ideological change gradually translated into economic institutions which, albeit not accompanied by political democratization, explicitly protected property against arbitrary expropriation, thus contributing to decades of sustained growth. In particular, leaders' authority was subjected to party rules, regional leaders were encouraged to protect property rights by linking their careers to economic performance, and more recently, private property was formally recognized by the Chinese constitution (Montinola et al. 1995; Weingast 1995; Xu 2011; Martinez-Bravo et al. 2012). At the 
same time, economists have noted that the Chinese court system remained undeveloped through the reform years, with judges being poorly trained and subordinate to party leaders, and that the low quality of contractual enforcement is now constraining China's development (Peerenboom 2002, Clarke et al. 2008, Xu 2011).

Our model suggests that, given the collectivist ideology and personalistic leader's rule inherited from the Cultural Revolution, the expropriation constraint $\left(\mathrm{EC}^{\mathrm{V}}\right)$ may have been initially tighter than the contract enforcement constraint $\left(\mathrm{EC}^{\mathrm{H}}\right)$. This may explain why the reformers' decision to forge a pro-growth ideology, and the consequent reshuffling in party ranks and economic reforms, have been so successful in promoting investment and growth. As the ruler's expropriation constraint $\left(\mathrm{EC}^{\mathrm{V}}\right)$ became gradually looser, though, a new equilibrium may have arisen where the contract enforcement constraint $\left(\mathrm{EC}^{\mathrm{H}}\right)$ is also binding. This, in turn, may have created a demand for improvements in the judicial technology, such as better training of courts and more efficient legal codes and procedures, aimed at relaxing such constraint.

\section{Why institutional rigidity?}

The model's applications to the Acemoglu and Johnson "puzzle" and to China raise some obvious questions. Why did colonies that inherited insecure property rights stick to them till the present? And why did China improve its property rights institutions only after Mao's death and, after seeing the reforms' economic success, did not pursue them more radically? In the language of our model: why doesn't the ruler cede his coercive power, thus relaxing the expropriation constraint $\left(\mathrm{EC}^{\mathrm{V}}\right)$ and raising effort and surplus? 
Our model suggests a possible explanation, consistent with previous research by Acemoglu (2003) and Acemoglu and Robinson (2012): while increasing efficiency, ceding power may permanently redistribute wealth away from the ruler, who will then have little incentive to cede power in the first place. While fully developing this argument is beyond the scope of our paper, we briefly sketch it below through an example, in part as a basis for future research, and in part to better microfound our model's application to the Acemoglu and Johnson "puzzle" and to China.

Suppose the ruler can irreversibly constrain his power in such a way that soldiers will no longer obey him if he orders them to expropriate. For instance, the ruler may train soldiers to be loyal to the State's constitution, rather than to him personally, and set up a professional rather than personalistic system for military recruitment.

Once the ruler permanently cedes power to "constitutional" soldiers, the principal is better off if he stops paying taxes to the ruler and negotiates a new agreeement with the agent and the soldiers, whereby the principal retains all of the output $(\gamma=0)$, and the soldiers expropriate it if the principal fails to pay the agent. Given the full expropriation threat, the principal has no incentive to deviate from such agreement. Moreover, the soldiers directly gain from expropriation, so they have no incentive to shirk on punishment. Finally, since soldiers are "constitutional", they have no incentive to expropriate unless the principal breaches. Since all constraints are slack, this new agreement that does not involve payments to the ruler generates first best surplus $\left(\mathrm{V}\left(\mathrm{e}^{\mathrm{FB}}\right)-\mathrm{C}\left(\mathrm{e}^{\mathrm{FB}}\right)\right)$, so it is both profitable for the principal and efficient. 
Unfortunately, the ruler's payoff under the new efficient agreement is zero. Moreover, the ruler cannot contract to trade his power in exchange for a large lump sum payment from the principal because, once he cedes power, the principal has no incentive to pay him, and once the principal pays, the ruler has no incentive to cede power. Anticipating that, if the ruler has power (for instance, because exogenous events allowed him or his predecessors to gather and consolidate such power in the past, as argued by Acemoglu and Johnson 2005), he will have no incentive to cede it, despite the efficiency gains that he would generate if he did so.

\section{Conclusion}

This paper has studied principal-agent contracts in the shadow of coercion. We have shown that, in the presence of repeated interactions, a State where the ruler uses power to enforce principal-agent contracts and does not use it to expropriate can arise as a selfenforcing equilibrium. We have also shown that, when the coercion technology is effective, higher production levels are feasible under the State, where contracts are enforced by the ruler, than under private ordering, where contracts are enforced by termination of the principal-agent relationship. Finally, we have shown that in a State, contract enforcement technology and constraints on the ruler's ability to expropriate are complementary inputs: improvements in the enforcement technology matter for efficiency only when the ruler's expropriation power is sufficiently constrained, and viceversa. Our results are consistent with the data on comparative institutions and development collected by Acemoglu and Johnson (2005), with the timing of economic and political reforms in 
post-Mao China (Weingast 1995; Clarke et al. 2008; Xu 2011), and with the historical transition from the "Law Merchant" private system of contract enforcement to the State (Milgrom et al. 1990; Masten and Prufer 2011).

Our model of contracts in the shadow of coercion may be extended in several directions. First, by allowing the ruler to also hire an agent, the model could be used to compare the productivity of private firms, whose owner does not have coercive power, with the productivity of public firms, whose owner-the ruler-does. In private firms, the agent can rely on the ruler to enforce his contracts with the principal, but he is also subject to a risk of expropriation by the ruler. Conversely, in public firms, principal-agent contracts must be enforced via private ordering even when coercive enforcement is more efficient, but the threat of ruler's expropriation disappears.

The model may also be used to study the provision of incentives in firms. Given its ownership of assets and its power to terminate employment relationships and to allocate tasks and rewards (Holmstrom and Milgrom 1994), the firm may be seen as a powerful "ruler". The firm's CEO may use his power to expropriate managers and employees (for instance, by changing piece rates or withdrawing discretionary bonuses and promotions), but also to enforce internal contracts between divisional managers and their subordinates (for instance, by immediately terminating a managers who fails to promote or pay the subordinate as promised, even when a replacement for the manager cannot be readily found, so that termination is costly for the firm). This may create a tradeoff between "private ordering" governance, where the promise of future rents is used to both enforce internal contracts and deter expropriation, and "State-like" firms, where future rents are 
used to deter expropriation while costly punishments are used to enforce internal contracts.

While these extensions are beyond the scope of the present paper, we hope to pursue them in future work.

\section{References}

ABREU, D., (1988), “On the Theory of Infinitely Repeated Games with Discounting," Econometrica 56: 383-396.

ACEMOGLU, D., (2003), "Why Not a Political Coase Theorem? Social Conflict, Commitment, and Politics," Journal of Comparative Economics 31: 620-652.

ACEMOGLU, D., and S. JOHNSON, (2005), "Unbundling Institutions," Journal of Political Economy 113: 949-995.

ACEMOGLU, D., S. JOHNSON, and J. ROBINSON, (2001), "The Colonial Origins of Comparative Development: An Empirical Investigation," American Economic Review 91: 1369-1401.

ACEMOGLU, D., S. JOHNSON, and J. ROBINSON, (2002), "Reversal of Fortune: Geography and Institutions in the Making of the Modern World Income Distribution," Quarterly Journal of Economics 117: 1231-1294.

ACEMOGLU, D., S. JOHNSON, and J. ROBINSON, (2005), "Institutions as a Fundamental Cause of Long-Run Growth," Chapter 6 in: P. Aghion and S. Durlauf (eds.), Handbook of Economic Growth, Vol. 1A: 385-472.

ACEMOGLU, D., and J. ROBINSON, (2012), Why Nations Fail, Crown Business: New York.

ARRUÑADA, B., (2003), "Property Enforcement as Organized Consent," Journal of Law, Economics and Organization 19: 401-444. 
BAKER, G., R. GIBBONS and K. J. MURPHY, (1994), "Subjective Performance Measures in Optimal Incentive Contracts," Quarterly Journal of Economics 109: $1125-1156$.

BAKER, G., R. GIBBONS and K. J. MURPHY, (1999), "Informal Authority in Organizations," Journal of Law, Economics and Organization 15: 56-73.

BAKER, G., R. GIBBONS, and K. J. MURPHY, (2002), "Relational Contracts and the Theory of the Firm," Quarterly Journal of Economics 117: 39-83.

BATTIGALLI, P., and G. MAGGI, (2002), "Rigidity, Discretion, and the Cost of Writing Contracts," American Economic Review 92: 798-817.

BENDOR, J., and D. MOOKHERJEE, (1990), "Norms, Third-Party Sanctions, and Cooperation," Journal of Law, Economics and Organization 6: 33-64.

BESLEY, T., and J. ROBINSON, (2009), "Quis Custodiet Ipsos Custodes? Civilian Control over the Military," London School of Economics, working paper.

BLAYDES, L., and E. CHANEY, (2013), "The Feudal Revolution and Europe's Rise: Political Divergence of the Christian West and the Muslim World before 1500 CE," American Political Science Review 107:16-34.

CLARKE, D., P. MURRELL, and S. WHITING, (2008), "The Role of Law in China's Economic Development," in Brandt, L., and T. Rawski (eds.), China's Great Economic Transformation, Cambridge: Cambridge University Press, pp. 319-361.

DE FIGUEIREDO, R., and B. WEINGAST, (2005), "Self-Enforcing Federalism," Journal of Law, Economics and Organization 21: 103-135.

DIXIT, A., (2003a), “On Modes of Economic Governance,” Econometrica 71: 449-481.

DIXIT, A., (2003b), “Trade Expansion and Contract Enforcement," Journal of Political Economy 111: 1293-1317.

DIXIT, A., (2004), Lawlessness and Economics, Princeton, NJ: Princeton University Press.

DJANKOV, S., R. LAPORTA, F. LOPEZ-DE-SILANES, and A. SHLEIFER, (2002), "The Regulation of Entry," Quarterly Journal of Economics 117: 1-37. 
DJANKOV, S., R. LAPORTA, F. LOPEZ-DE-SILANES, and A. SHLEIFER, (2003), "Courts," Quarterly Journal of Economics 118: 453-517.

ELLICKSON, R., (1991), Order without Law: How Neighbors Settle Disputes, Cambridge, MA: Harvard University Press.

GLAESER, E., and A. SHLEIFER, (2002), "Legal Origins," Quarterly Journal of Economics 117: 1193-1229.

GREIF, A., (2006), Institutions and the Path to the Modern Economy: Lessons from Medieval Trade, New York: Cambridge University Press.

GREIF, A., P. MILGROM, and B. WEINGAST, (1994), "Coordination, Commitment, and Enforcement: The Case of the Merchant Guild," Journal of Political Economy 102: $745-776$.

GROSSMAN, S., and O. Hart, (1986), "The Costs and Benefits of Ownership: A Theory of Vertical and Lateral Integration," Journal of Political Economy 94: 691-719.

GURR, T., (1999), "Polity II: Political Structures and Regime Change, 1800-1986," ICPSR working paper 9263.

HADFIELD, G., and B. WEINGAST, (2012a), "What is Law? A Coordination Model of the Characteristics of Legal Order," Journal of Legal Analysis 4: 471-514.

HADFIELD, G., and B. WEINGAST, (2012b), "Law without the State: Legal Attributes and the Coordination of Decentralized Collective Punishment," Journal of Law and Courts 1: 3-34.

HOLMSTROM, B., (1979), "Moral Hazard and Observability,” Bell Journal of Economics 10: 74-91.

HOLMSTROM, B., and P. MILGROM, (1994), “The Firm as an Incentive System," American Economic Review 84: 972-991.

KLEIN, B. (2000), "The Role of Incomplete Contracts in Self-Enforcing Relationships," Revue d'Economie Industrielle 92: 67-80.

KLEIN, B., and K. LEFFLER, (1981), "The Role of Market Forces in Assuring Contractual Performance," Journal of Political Economy 89: 615-641. 
KONTLER, L., (2006), A History of Hungary, Palgrave Macmillan.

GIBBONS, R., and A. RUTTEN, (2007), "Hobbesian Horseraces," working paper.

LEVIN, J., (2002), "Multilateral Contracting and the Employment Relationship," Quarterly Journal of Economics 117: 1075-1103.

LEVIN, J., (2003), "Relational Incentive Contracts," American Economic Review 93: 835-857.

LIBECAP, G., and D. LUECK, (2011), "The Demarcation of Land and the Role of Coordinating Property Institutions," Journal of Political Economy 119: 426-467.

MACLEOD, B., (2007), "Reputations, Relationships, and Contract Enforcement," Journal of Economic Literature 45: 595-628.

MACLEOD, B., and J. MALCOMSON, (1989), "Implicit Contracts, Incentive Compatibility, and Involuntary Unemployment," Econometrica 57: 447-480.

MARTINEZ-BRAVO, M., PADRO-I-MIQUEL, G., QIAN, N., and Y. YAO, (2012), "The Effects of Democratization on Public Goods and Redistribution: Evidence from China”, National Bureau of Economic Research Working Paper 18101.

MASTEN, S., and J. PRUFER, (2011), "On the Evolution of Collective Enforcement Institutions: Communities and Courts," Tilburg University Working Paper.

MILGROM, P., D. NORTH, and B. WEINGAST, (1990), "The Role of Institutions in the Revival of Trade: The Law Merchant, Private Judges, and the Champagne Fairs," Economics and Politics 2: 1-23.

MONTINOLA, G., QIAN, Y., and B. WEINGAST, (1995), "Federalism, Chinese style: the Political Basis for Economic Success in China," World Politics 48: 50-81.

MYERSON, R., (2008), "The Autocrat's Credibility Problem and Foundations of the Constitutional State," American Political Science Review 102: 125-139.

NADER, L. (ed.) (1969). Law in Culture and Society, Berkeley, CA: University of California Press. 
NORTH, D., J. WALLIS, and B. WEINGAST, (2009), Violence and Social Orders: A Conceptual Framework for Interpreting Recorded Human History, Cambridge: Cambridge University Press.

OLSON, M., (1993), “Dictatorship, Democracy, and Development," American Political Science Review 87: 567-576.

ONORATO, M., K. SCHEVE, and D. STASAVAGE, (2012), "Technology and the Era of the Mass Army," working paper.

PEERENBOOM, R. (2002), China's Long March Toward Rule of Law. Cambridge, UK: Cambridge University Press.

WEINGAST, B., (1995), “The Economic Role of Political Institutions: MarketPreserving Federalism and Economic Development," Journal of Law, Economics and Organization 11: 1-31.

XU, C. (2011), “The Fundamental Institutions of China's Reforms and Development," Journal of Economic Literature 49: 1076-1151.

ZANARONE, G., (2013), "Contract Adaptation under Legal Constraints," Journal of Law, Economics and Organization 29 (forthcoming). 


\section{Figure 1. Private ordering}

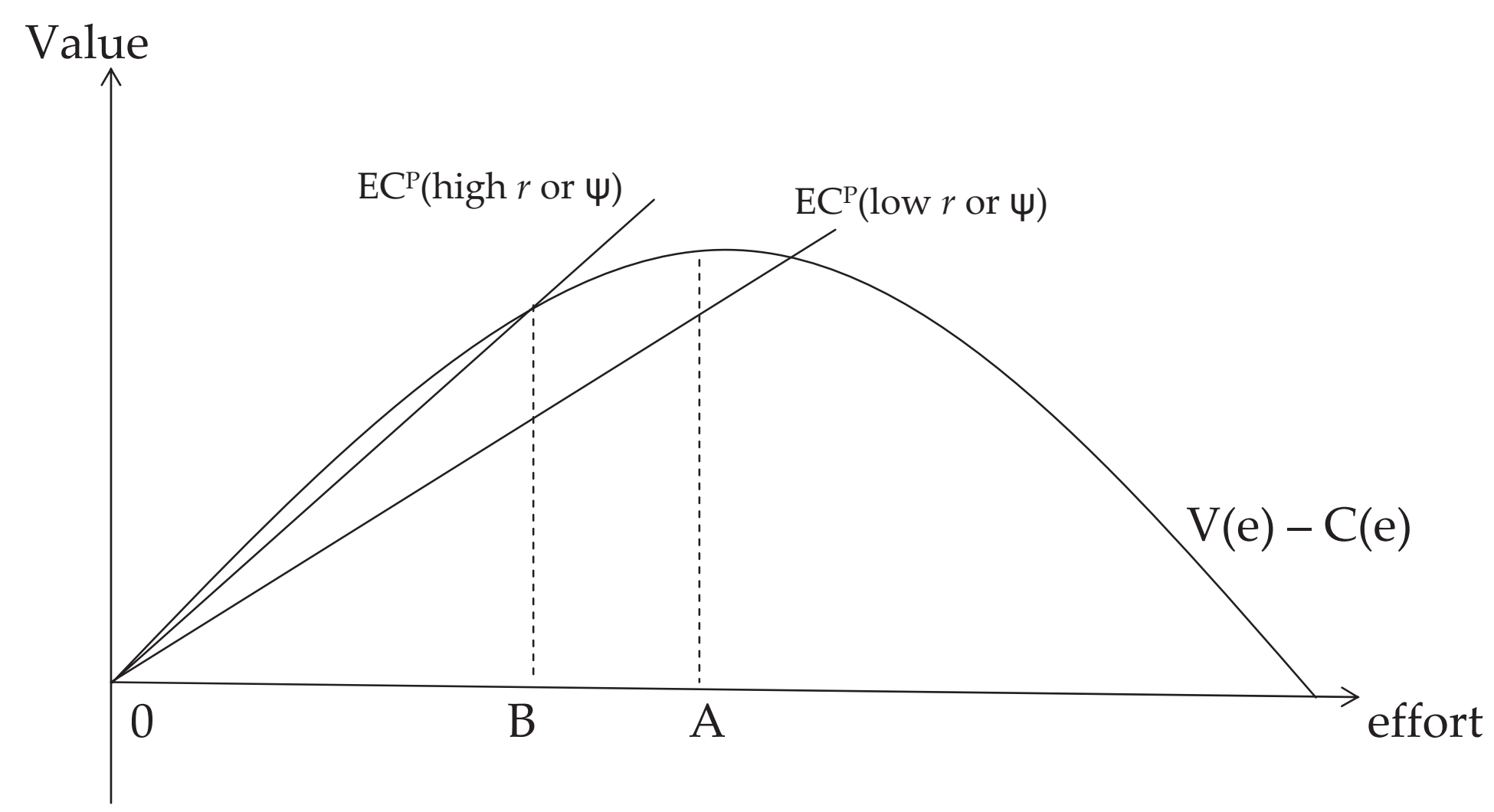

Figure 1 depicts the private ordering equilibrium of the model. Point A corresponds to the first best. With a low discount rate, the parties can construct a credible enforcement contract that sustains the first best (EC $C^{\mathrm{P}}$ is slack in this case). As the discount rate increases (higher $r$ or $\psi$ ) the non-expropriation constraint $\mathrm{EC}^{\mathrm{P}}$ starts to bind, and only the effort up to a second-best point $\mathrm{B}$ can be credible contracted. 


\section{Figure 2. State: interplay of contract enforcement and expropriation}

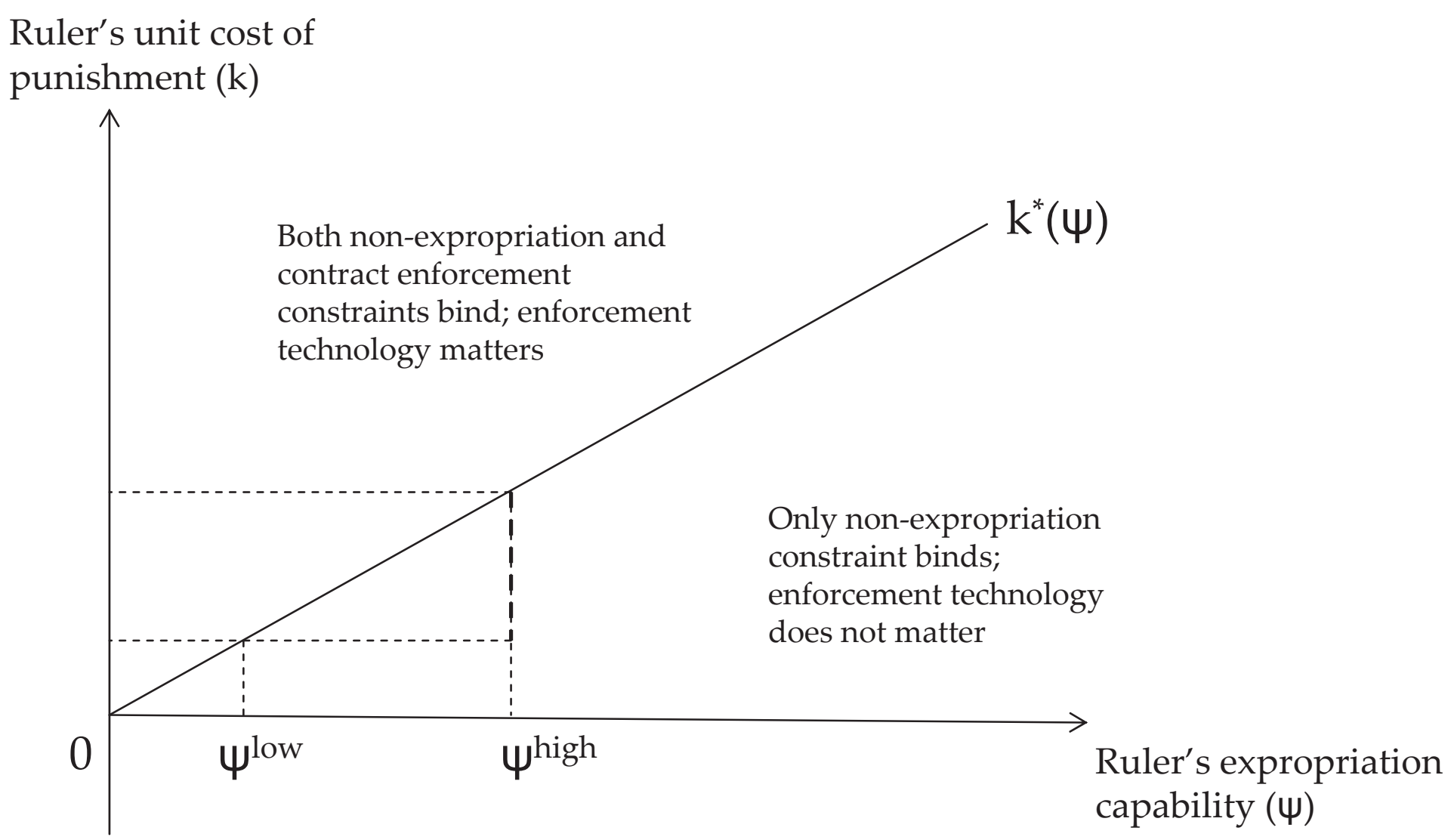

Figure 2 depicts the sets of parameters such that the contract enforcement technology does or does not matter for efficiency. For coercion costs below the $\mathrm{k}^{*}(\Psi)$ line, the contract enforcement constraint does not bind, so the enfoircement technology does not matter (Cfr. Figure $\left.2 \mathrm{a}\right)$. The reverse is true above the line (Cfr. Figures $2 \mathrm{~b}$ and $2 \mathrm{c}$ ). The bold dotted segment shows how the region where the enforcement technology does not matter expands as $\Psi$ gets larger (Proposition 4 ). 


\section{Figure 3a. Improvements in enforcement technology in a State with unconstrained ruler}

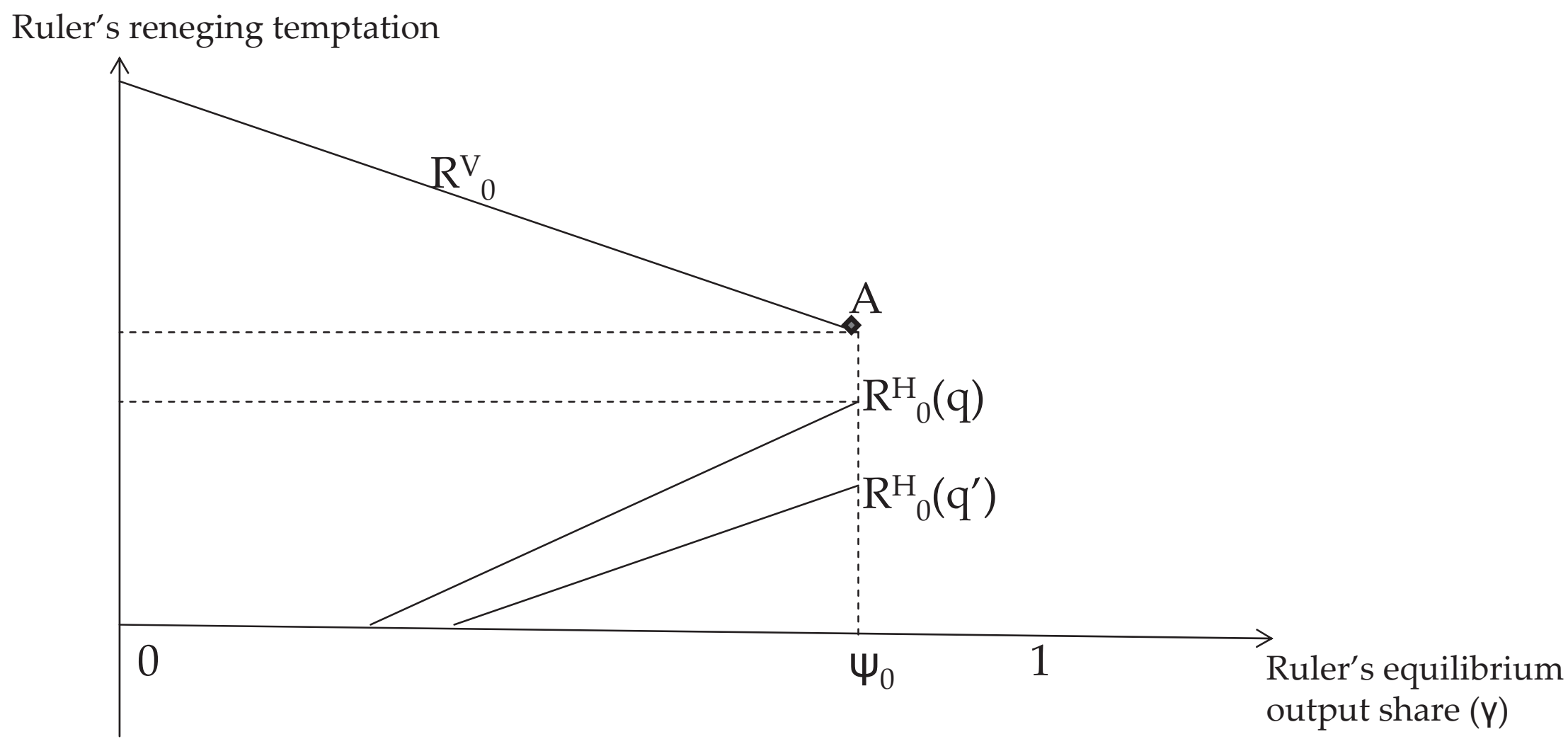

Figure 3a depicts the equilibrium in settings where only the non-expropriation constraint of the Ruler binds, whereas the contract enforcement constraint is slack. The condition for this is that $R^{H}$ is below $R^{V}$ even for $Y=\Psi_{0}$ (i.e. under maximum expropriation allowed), so that setting $\gamma=\Psi_{0}$ is optimal. An exogenous improvement in contract enforcement technology (i.e., an increase in q) does not change the equilibrium point $\mathrm{A}$, because it does not relax the ruler's binding constraint. 


\section{Figure 3b. Improvements in enforcement technology in a State with moderately constrained ruler}

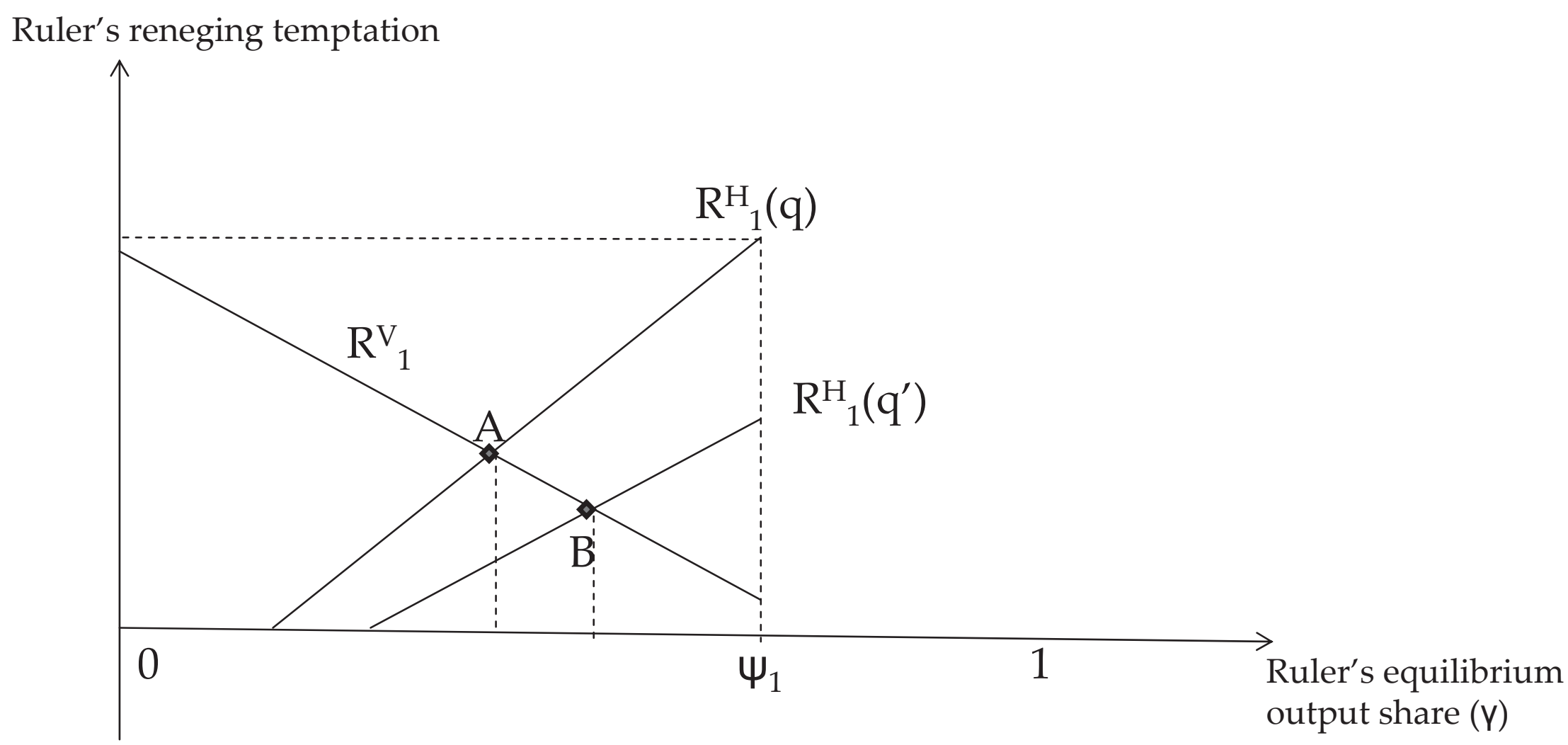

Figure $3 \mathrm{~b}$ depicts the equilibrium in settings where both the non-expropriation and the contract enforcement constraints of the Ruler bind. The conditions for this are that (1) $R^{H}$ is above $R^{V}$ for $\gamma=\psi_{1}$, so that setting $\mathrm{Y}<\psi_{1}$ is optimal, and (2) $R^{H}$ is below $R^{V}$ for $\gamma=0$, so that there is a $Y$ such that $\mathrm{R}^{\mathrm{H}}=\mathrm{R}^{\mathrm{V}}$. An exogenous improvement in contract enforcement technology (i.e., an increase in $\mathrm{q}$ ) moves the equilibrium from point $\mathrm{A}$ to the more efficient point $\mathrm{B}$ because it relaxes one of the ruler's two binding constraints. 


\section{Figure 3c. Improvements in enforcement technology in a State with highly constrained ruler}

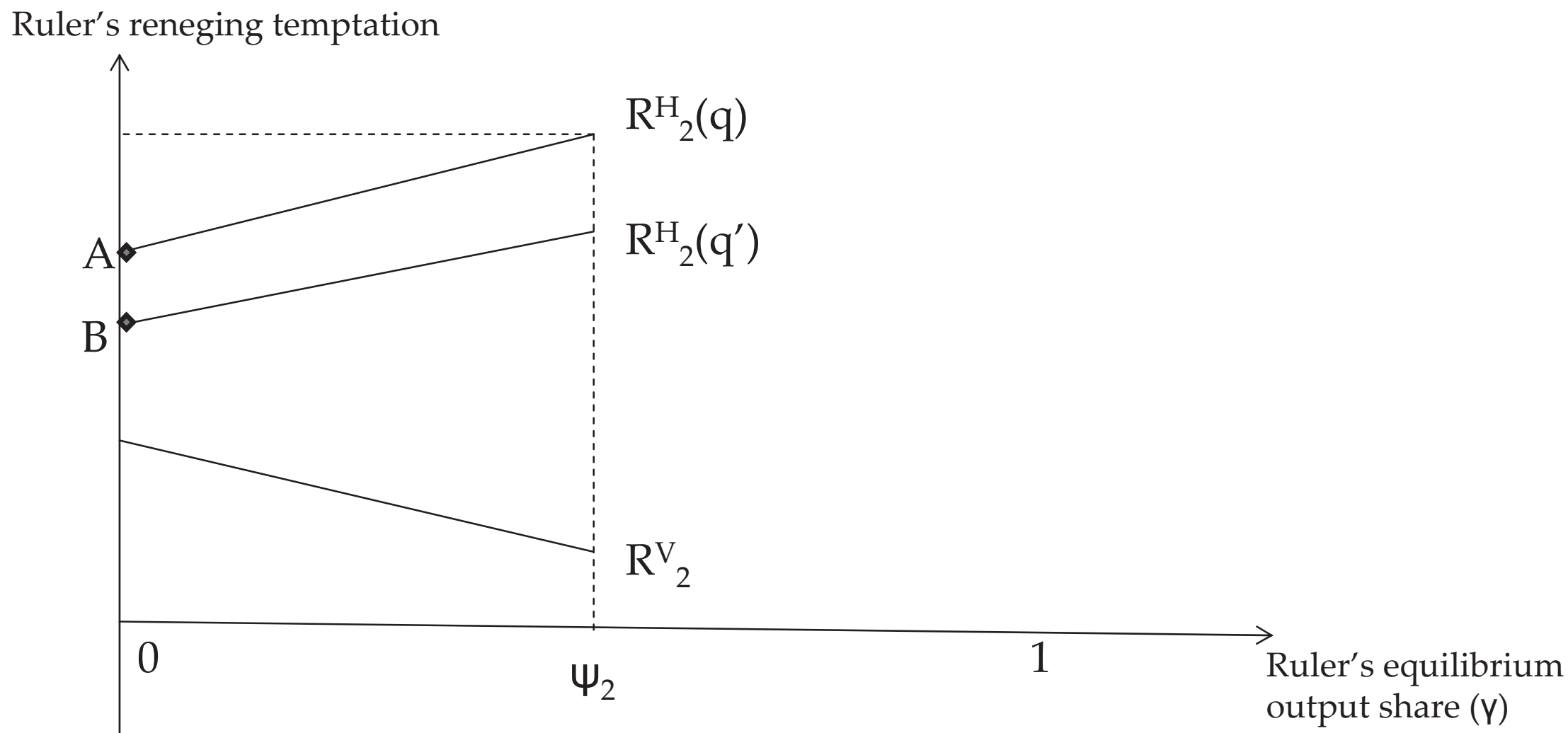

Figure $3 c$ depicts the equilibrium in settings where only the contract enforcement constraints of the Ruler binds. The condition for this is that $\mathrm{R}^{\mathrm{H}}$ is above $\mathrm{R}^{\mathrm{V}}$ even for $\mathrm{Y}=0$, so that setting $\mathrm{Y}=0$ is optimal. An exogenous improvement in contract enforcement technology (i.e., an increase in q) moves the equilibrium from point $\mathrm{A}$ to the more efficient point $\mathrm{B}$ because it relaxes the ruler's binding constraint. 
Table 1. Effect of enforcement and non-expropriation institutions on income per capita

\begin{tabular}{|c|c|c|c|c|c|}
\hline & (1) & (2) & (3) & (4) & (5) \\
\hline & \multicolumn{5}{|c|}{ Dependent variable: log GDP per capita in 1995, PPP } \\
\hline Legal formalism & -0.002 & -0.501 & 0.425 & 4.974 & 0.457 \\
\hline & $(0.211)$ & $(0.333)$ & $(0.236)$ & $(2.892)$ & $(0.382)$ \\
\hline Constraints on executive (avg. for 1990s) & 0.878 & 1.132 & -0.281 & 4.174 & 0.680 \\
\hline & $(0.273)$ & $(0.554)$ & $(0.490)$ & $(2.087)$ & $(0.252)$ \\
\hline Interaction term & & & & -0.942 & -0.105 \\
\hline & & & & $(0.526)$ & $(0.066)$ \\
\hline Constant & 3.805 & 4.127 & 7.094 & -13.839 & 4.907 \\
\hline & $(1.710)$ & $(3.085)$ & $(2.346)$ & $(11.480)$ & $(1.475)$ \\
\hline Observations & 60 & 28 & 32 & 60 & 60 \\
\hline Method & $2 S L S$ & $2 S L S$ & $2 \mathrm{SLS}$ & $2 \mathrm{SLS}$ & OLS \\
\hline Instruments & $\begin{array}{l}\text { UK legal origin; } \\
\text { Log population } \\
\text { density in } 1500\end{array}$ & $\begin{array}{l}\text { UK legal origin; } \\
\text { Log population } \\
\text { density in } 1500\end{array}$ & $\begin{array}{l}\text { UK legal origin; } \\
\text { Log population } \\
\text { density in } 1500\end{array}$ & $\begin{array}{l}\text { UK legal origin; } \\
\text { Log population } \\
\text { density in } 1500 ; \\
\text { interaction } \\
\text { between them }\end{array}$ & No instruments \\
\hline Sample & Full ex-colonies & $\begin{array}{l}\text { Ex-colonies with } \\
\text { log pop density in } \\
1500 \text { s }<\text { median }\end{array}$ & $\begin{array}{l}\text { Ex-colonies with } \\
\text { log pop density in } \\
1500 \text { s }>\text { median }\end{array}$ & Full ex-colonies & Full ex-colonies \\
\hline
\end{tabular}

Notes: Data are the original Acemoglu and Johnson (2005) dataset. Standard errors in parentheses. 